\title{
Influence of Early Literacy Parental Involvement on Science Achievement of Junior Secondary School Students in Nigeria.
}

\author{
Dr. Bimbola D. Oludipe*
}

\begin{abstract}
Influence of early literacy on science achievement of Junior Secondary School students was examined in this study. The sample consisted of 360 Junior Secondary School II (JSSII) students(162 females and 198 males, mean age 13.47years, $S D=0.746)$ randomly selected from 12 co-educational junior secondary schools in Osun state, Nigeria. An achievement test (Integrated Science Achievement Test, 'INSAT') and a questionnaire (Early Literacy Parent Involvement Questionnaire, 'ELIPIQ') were used for data collection. The Cronbach coefficient alpha value for the questionnaire was found to be 0.62 while Reliability estimates of 0.74 was established for the achievement test. Findings revealed that: of the 360 parents involved in this study, only about $20.8 \%$ were highly involved in their children's early literacy acquisition; parental involvement in literacy acquisition of boys was more than that of girls, though this difference was not significant; a positive relationship between parental involvement in early literacy acquisition and students' science achievement was found and, parental involvement in children's early literacy acquisition predicted only $0.280(28 \%)$ of the variation of achievement in science $\left(R^{2}=0.280\right)$ and a positive but weak $(r=0.183)$ significant relationship between parents' educational attainment and their involvement in literacy acquisition of their children was also found. It was therefore recommended that parents should be more involved in early literacy acquisition of their children by spending time to read with them, share stories, recite rhymes, jingles, poetry, and so on.
\end{abstract}

* Technology Department, Faculty of Education, Olabisi Onabanjo University, Ago-Iwoye,Ogun State, Nigeria

E-mail: bimbolaoludipe@yahoo.com 


\section{INTRODUCTION}

Science permeates our lives and informs our actions and the pursuance of science or science education has social, political and economic impact on our society. Science and its applications have improved lifestyle in the areas of communication, agriculture, medicine, industry and aviation. Scientific principles have also provided the basis for inventions such as television, telephone, radio, refrigerator, computers, cars, ship, airships, nuclear weapons, warships and so on. The goal of all sciences is to develop scientifically literate citizens who can think and act rationally. Africa has a growing awareness of the importance of science and is being transferred from a predominantly traditional continent where taboos and superstitions thrive, to a more dynamic and more informed society. Nonetheless, the goal of self-reliance with respect to scientific and technological human power development have not been achieved due to various socio-economic obstacles vis-a-viz political instability, high population growth rate, ravaging inflation, collapsed economics, environmental pollution, deterioration of infrastructure, high levels of unemployment, falling standard of education, excessive debt burdens, shortage of Science and Technology personnel, increase in the absolute number of illiterates and the brain drain (Ogunniyi, 1996). In the school system, reports have it that relative to other schools subjects, African students are not performing well in Science Technology and Mathematics (STM); are not positively disposed to the study of STM; have severely limited opportunities for experimentation and problem-solving activities; perform below expectation in continuous assessment in STM: and do not consistently demonstrate certain desirable scientific attributes such as critical thinking, objectivity and persistence (STAN, 1992; Marope 1992; Kam \& Motsomi 1992, Ogundipe, 2004).

In Nigeria for instance, students performances in the Sciences in WAEC is not encouraging and is dwindling by the day (WAEC Research and Statistics Unit, 2008). Several factors have been identified to contribute to students' poor performance in STM. Among others, a review of the literature shows the following factors to be critical; the school environment, home environment, students factors, teachers factors, nature of subject, Government policies, and so on(STAN, 1992; Prophet 1990; Liu, 2001; Yip 2001).

The "home" is very germane and crucial to a child's well-being and development in latter life. This is because parents in the home are children's first teacher. From the day a child is born and begins to hear, he/she begins to develop literacy as parents and other caring adults and preschool teachers speak, play, sing and read to them. As a child moves from infant to toddler and then to preschooler, he learns to be able to read, write, listen and speak. Early literacy development is a significant part of preparing children to achieve academically. Basic literacy activities that are associated with children's engagement with texts and success in reading were identified by literacy researchers (Snow, Burns \& Griffin, 1998; Whitehurst \& Longman, 1998; Dickinson \& Tabors, 2001; Wasik \& Band 2001) include; Oral language development, which includes book reading, phonemic awareness activities (acquired through nursery rhymes, jingles, poetry, and books that contain words with thymes) and, exposure to the alphabet.

The influence of parents especially, mothers on children's early literacy acquisition and subsequent school achievement is well documented in numerous studies (Trusty, 1998; Yan \& Lin 
2002; Gadsden \& Ray, 2003). Research shows that greater parental involvement in children's learning positively affects the child's school performance including higher academic achievements (McNeal, 1999; Scribner, Lin, 2003); and greater social and emotional development (Bredekamp \& Copple, 1997; Fantuzzo \& McWayne, 2002). Parents not only provide mediated learning experiences and through talking with the child, sharing experiences and teaching, but also help organize a child's learning experiences (Okunola 2004). Simple interactions, such as reading to young children, may lead to greater reading knowledge and skills (Snow, Burns \& Griffin, 1998). Also, children with richer home literacy environments demonstrate higher levels of reading knowledge and skills at Kindergarten entry (Nord, Lennon, Lin \& Chadler, 2000). Parental reports of provision of appropriate play materials and opportunities for variety of activities during infancy are correlated with higher intelligence, test scores and teacher ratings of child intelligence, curiosity and creativity during Kindergarten (Schaefer \& Edgerton, 1985). Corroborating earlier findings, Lin (2003) found that home resources among others predicted almost all Kindergarten's (children considered in this study) early literacy skills, except for Asian children's reading and math.

From the Foregoing, research evidences have shown that parental involvement in children's early literacy acquisition influences a child's school achievement especially in reading knowledge and skills, general knowledge and school mathematics knowledge and skills (Reaney, Denton and West, 2002). However, there is a dearth of literature on how early literacy acquisition could influence students' achievement in Science. This is therefore the main thrust of this paper which, is borne out of the need to ameliorate the problem of poor achievement and improve students' achievement in science. Findings and conclusions from this study would reflect the contemporary educational trend in Nigeria which demands that such an issue be critically examined in our context. The Science considered here is integrated science. The choice of integrated science is borne out of the fact that optional revitalization of cognitive outcome in science must be approached from the grass root of Integrated science, which is the gateway to the learning of science as it subsumes primary sciences and paves way for other specialized scientific disciples (eg. Physics, chemistry, biology etc).

\section{Research Questions}

1. What is the level of parental Involvement in children's literacy acquisition?

2. Is there any significant difference between parental Involvement in literacy acquisition of Boys and Girls?

3. Is there any relationship between parental involvement in early literacy acquisition and students' achievement in Integrated science?

4. To what extent would parental involvement in children's early literacy acquisition predict achievement in science?

5. Is there any relationship between parents' Educational attainment and their involvement in early literacy acquisition of their children?

\section{METHODOLOGY}

This study is an expost-facto type of research.

\section{Population and Sample}

The target population was made up of all Junior Secondary School II Integrated 
Science students in Osun State, Nigeria. Osun State is made up of thirty Local Government areas. These Local Governments were divided into two strata by the researcher. One Local Government was picked from each stratum. The two Local Governments selected (Ife-East and Ayedaade) had 17 and 15 public secondary Schools respectively. Purposive sampling method was used to select $40 \%$ of the Schools in each of these Local Governments. In all, 12 co-educational secondary schools were selected. These schools were picked on the ground that they are co-educational and the students are offering Physics. Thereafter, simple random sampling was used to select 400 students (200 males and 200 females) from these schools. After the completion of the questionnaire, only 360 of them (from 162 females and 198 males ) alongside the achievement test were returned to the researcher. The ages of the students range from 12.4years and 15.7years with the mean coming to 13.47 years ( SD, 0.746).

\section{INSTRUMENTS}

One questionnaire and one achievement test were used for data collection. The Questionnaire, titled: Early Literacy Parent Involvement Questionnaire (ELIPIQ) was developed by the Reading and Speech Clinic and adapted for use in this study. It was designed for parents to elicit information on their wards. It was made up of two sections, A and B. Section A sought some socio-economic background information from parents. Section B was made up of 30 items on a 3 point-scale of Always, Sometimes and Never. To these, parents were required to indicate their degree of involvement with early literacy acquisition of their children. The instrument was made up of five parent involvement composites- Reading Books, Response to Prints, Language awareness, Interest in Letters and writing. The
Cronbach coefficient alpha value was found to be 0.62 .

The second instrument was an Integrated Science Achievement Test (INSAT) developed by this researcher. It was made up of 24 items in essay format, picked from concepts of Energy. Living things, gravitation, pollution and weather in the JSS III curriculum. Difficulty and discrimination indices of each of the items in this instrument was computed. Items with positive discrimination and difficulty (facility) indices of between 0.45 and 0.65 were retained. Reliability estimates of 0.74 was established for the test using test retest method.

\section{Procedure for Data Collection}

The students (with the help of their integrated Science teachers as research assistants) were made to sit in their classroom under normal classroom conditions. The questionnaire were given to the students to take home to their parents for completion with a stipulated date of three days for them to be returned failure of which led to the refusal to collect the instrument back. Three hundred and sixty of these students complied and it was only those that had the opportunity of taking the Integrated Science achievement test. The achievement test was then administered on all the students during the morning hours and it lasted for one hour. After completion, the instruments were collected back and scored.

\section{Scoring of Instrument}

For the 24-item achievement test, each correct answer attracted one point. The minimum score was zero and the maximum, 24. For the questionnaire, the responses- "Always", "Sometimes" and "Rarely" attracted points 3, 2 and 1 respectively. The maximum score was 90 while the minimum was 30 . 


\section{Data Analysis}

Data were analysed using frequency counts, percentages, Pearson Product Moment correlation, regression and t-test analyses.

\section{RESULTS}

Research Question 1. What is the level of parental Involvement in children's literacy acquisition?

Table 1: Frequency Analysis of parental Involvement in children’s literacy acquisition

\begin{tabular}{lcc}
\hline Level of Involvement of parents & Frequency & $\%$ \\
\hline Highly Involved & 75 & 20.8 \\
\hline Moderately involved & 115 & 31.9 \\
\hline Less involved & 170 & 47.2 \\
\hline TOTAL & 360 & $100 \%$ \\
\hline
\end{tabular}

Table 1 revealed that of the 360 parents involved in this study, 25 (20.8\%) were highly involved in their children's early literacy acquisition; 115 (31.9\%) were moderately involved and, 170 (47.2\%) were less involved. This is buttressed by the figure below.

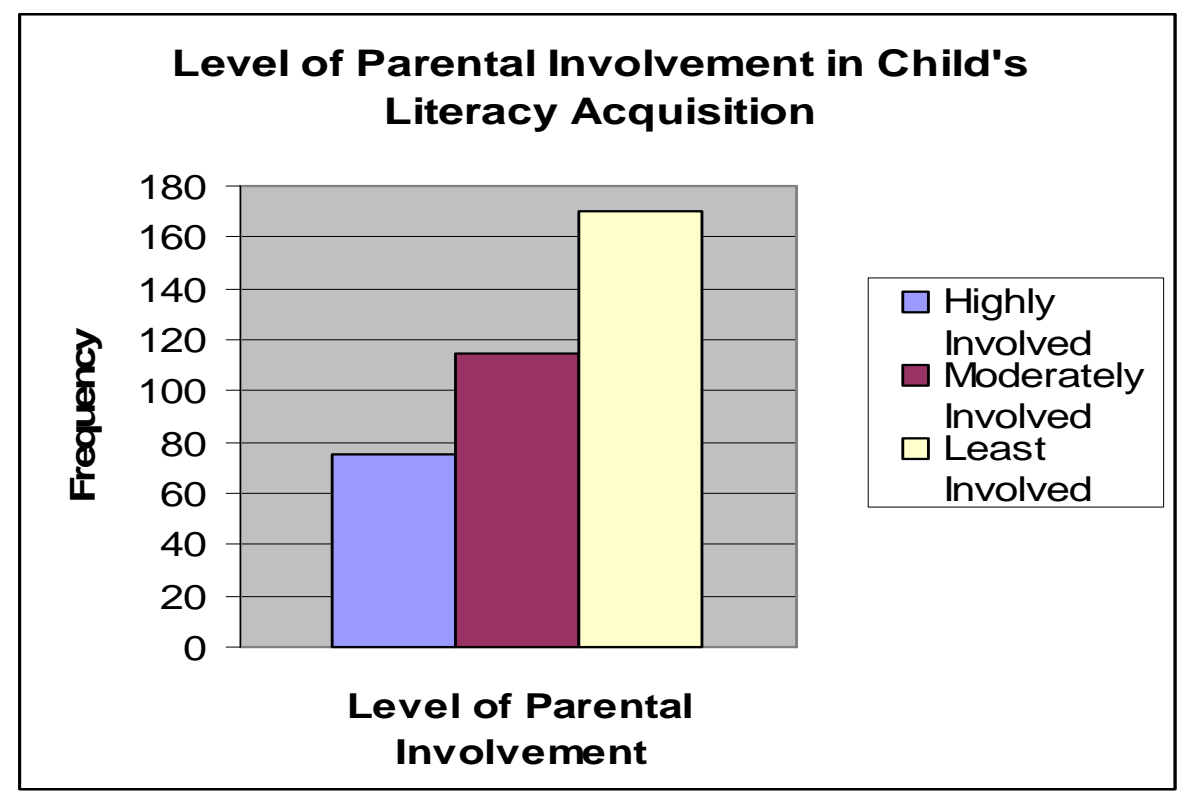


Research Question 2. Is there any Involvement in literacy acquisition of significant difference between parental Boys and Girls?

Table 2. t-test comparison of parental Involvement in literacy acquisition of male and female students

\begin{tabular}{lllllll}
\hline Sex & $\mathbf{N}$ & df & Mean & SD & t & Remark \\
& & & & & & \\
\hline Male & 198 & 358 & 51.01 & 15.13 & 0.157 & $\begin{array}{l}\text { Not } \\
\text { significant }\end{array}$ \\
\hline Female & 162 & & 48.51 & 14.73 & & \\
\hline
\end{tabular}

Table 2 revealed that parental involvement in literacy acquisition of boys was more than that of girls, however, this difference was not significant. This therefore implies that parental involvement in literacy acquisition of boys and girls in this study were to the same degree.
Research Question 3. Is there any relationship between parental involvement in early literacy acquisition and students' achievement in Integrated science?

Table 3: Relationship between parental involvement in early literacy acquisition and students' achievement in Integrated science?

\begin{tabular}{lcccccc}
\hline & N & Mean & SD & df & r & Remark \\
\hline Parental Involvement & 360 & 14.73 & 3.079 & 358 & 0.531 & significant \\
\hline Science achievement & 360 & 49.88 & 4.982 & & & \\
\hline
\end{tabular}

Table 3 revealed a positive but average relationship between parental involvement in early literacy level acquisition and students' achievement in integrated science and this was found to be significant at 0.01 level of significance.
Research Question 4. To what extent would parental involvement in children's early literacy acquisition predict achievement in science? 
Table 4a: Regression Analysis of Parental involvement in children's early literacy acquisition and achievement in science?

\begin{tabular}{|c|c|c|c|c|c|}
\hline $\begin{array}{ll}\text { Source } & \text { of } \\
\text { Variation } & \end{array}$ & $\begin{array}{l}\text { Sum } \\
\text { square }\end{array}$ & of df & $\begin{array}{l}\text { Mean } \\
\text { square }\end{array}$ & F-ratio & Remark \\
\hline Regression & 960.728 & 1 & 960.728 & 140.747 & significant \\
\hline Residual & 2443.672 & 358 & 6.826 & & \\
\hline Total & 4947.082 & 359 & & & \\
\hline
\end{tabular}

Table 4b

$$
\begin{aligned}
& \mathrm{R}=0.531 \\
& \mathrm{R}^{2}=0.282 \\
& \text { Adjusted } \mathrm{R}^{2}=0.280 \\
& \text { Standard Error of Estimate }=2.613
\end{aligned}
$$

Table 4b revealed that parental involvement in children's early literacy acquisition

predicted only 0.280 (28\%) of the variation of achievement in science $\left(\mathrm{R}^{2}=0.280\right)$. Table 4a showed a significant F-ratio of 140.747 , which implies that the $\mathrm{R}^{2}$ is not due to chance.

Table5: Analysis of the Relationship between Parents' Educational attainment and their involvement in early literacy acquisition of their children?

\begin{tabular}{lcccccc}
\hline & N & Mean & SD & df & r & Remark \\
\hline Parental Involvement & 360 & 1.74 & 0.783 & 358 & 0.183 & significant \\
\hline Science achievement & 360 & 3.57 & 0.976 & & & \\
\hline
\end{tabular}

Research Question 5. Is there any relationship between parents' Educational attainment and their involvement in early literacy acquisition of their children? 
Table 5 revealed a positive but weak significant relationship between parents' educational attainment and their involvement in literacy acquisition of their children.

\section{DISCUSSION OF FINDINGS}

The first finding in this study agrees with those of McNeal, 1999; Scribner, Young \& Pedroza, 1999; Lin, 2003). Most parents are not highly involved in early literacy acquisition of their children as revealed by the first finding of this study. In the home, mothers are the first teachers of their children. They are the caregiver and minder of the child during the critical period of their development, though the father does as well (Brimhall and West, 1997; Gadson and Ray, 2003), however, problem arises from the fact that the jobs of so many parents are so demanding and this may explain why they do not have ample time for their children. Meanwhile parents' involvement in their children's acquisition of literacy is very important as this (third finding) influences students's science achievement. This finding agrees with those of Gardsden and Bowman, (1999), Gadson and Ray (2003). Since literature has revealed that father's involvement is also a powerful factor in children's achievement, father and mother can create time in turn to be available for their children. However, not every home can give a child all the experiences of early literacy. To this end, parents can engage the services of preschool teachers or other caring adults to handle this task. Another finding revealed that parents were involved with boys and girls to the same degree. This was the second finding in this study. This tends to suggest that there was no favouritism or discrimination along this line among the time spent with both boys and girls. Evidences abound in research that showthat girls are always discriminated against and boys are unduly favoured. However, any form of favouritism or discrimination will only hamper girls from realizing same literacy level with boys and subsequently prevent them from contributing their own quota to the manpower needed to develop science and technology. Every child has a potential to learn science as science is all over us. Children are naturally curious and desire to explore and experiment. Science education feeds that curiosity at an early stage and provides children with valuable concepts, life skills and career options. Parents need to share with their children at an early stage in life so that they can have a firm base of knowledge to build on when they get to school.

This study also revealed a positive but weak significant relationship between parents' educational attainment and their involvement in their children's literacy acquisition. It is however surprising that the relationship is weak though it was positive. This likely implies that parents' educational attainment is crucial to students' involvement in early literacy acquisition. This was corroborated by Osanyin (1998). It is reasonable to expect that the higher a parent's educational attainment, the more involved he/ she would be involved with his/her children. This researcher equally agrees with Nord, Lennon, Lin and Chadler, (2000) that children from homes that have richer literacy environment will demonstrate higher levels of knowledge. In homes where parents are less literate on the other hand, this should not be an impediment; they can still engage the services of other caring adults like the child's siblings or baby minders carry out these activities or they can make the media available (if they can afford them). 


\section{CONCLUSION AND RECOMMENDATIONS}

Early literacy development is a significant part of preparing children to achieve academically in school and to be socially and emotionally balanced. Parent involvement with children is at this early stage is very crucial to foster language development, phonemic awareness activities and a child's educational attainment latter in school. Spending quality time to read with children, sing for them, share stories, recite rhymes, jingles, poetry, and pronounce alphabets, is very important to children's acquisition of knowledge. Parents should therefore not jeopardize their children's future by neglecting this duty. Mothers should not be saddled with all the responsibility, fathers should be readily available and other elderly siblings in the family can assist their younger ones.

\section{REFERENCES}

Ali, M. (2007). "Use Science, Technology to develop Africa”. http//allafrica.com/ stories/200707120189.html

Archived Learning Partners - Let's Do Science.

http://www.ed.gov/pubs/parents/Learnptnrs sscience.html

Bredekamp, S \& Copple, C.(1997). Developmentally appropriate practice in early childhood programs. Washington, DC: National Association for the Education of Young Children.

Comer, J.P \& Haynes, N.M (1991). Parent Involvement in Schools: An ecological approach. The Elementary School Journal 91(3), 271-277.
Dauber, S.L \& Epstein, J. L. (1993). Parents' attitudes and Practices of involvement in inner city elementary and middle Schools. In N. F. Charkin (Ed.), Families and Schools in a pluralistic Society (pp 53-71). Albany, NY: Suny Press.

Dickinson, D.K \& Tabors, P. O. (Eds.). (2001). Beginning Literacy with Language: Young Children learning at home and School. Baltimore, MD: Brookes. ED 450972.

Early Literacy Parent Questionnaire (2007). Reading and Speech Clinic, Inc. www.readingandspeechclinic.com/forms/E arly\%20literacy \%20Parent\%20Questionnaire-1.pdf.

Fantuzzo, J \& Mc Wayne, (2002). The Relationship between peer- play interactions in the family context and dimensions of school readiness for lowincome preschool children. Journal of Educational Psychology, 94(1),

79-87.

Federal republic of Nigeria National Policy on Education. NERDC Press, Lagos, Nigeria. pg 29.

Gadsden, V \& Ray, A. (2003). Fathers' Role in Children's Academic Achievement and Early Literacy. ERIC digest.

Helping your children to learn - Parents Centre.

www.parentscentre.gov.uk/schoollife/helpy ourchildrentolearn/

Inter-Union Commission on Science
Teaching(ICSU)(1968).Congress on the
Integration of Science Teaching:
Conclusion.

Kann, U. and Motsomi S.(1992). Teaching learning conditions in academic secondary 
schools. In U. Kann and M. Nganunu (eds). A Project of the ITEP (Paris: UNESCO), pp 60-79.

Koralek, D. (1997). Conversations that count: How do crawlers and Walkers Learn?

http://www.readingrockets.org/article/185

Lin, Q. (2003). Parent Involvement and Early Literacy. http://www.gse.harvard.edu/hfrp/projects/fi ne/resources/digest/literacy.html

Liu, X.F (2001). Synthesizing research an student conceptions in Science. International Journal of Science Education 23(1), $55-81$.

Marope, P.T.M. (1992). Determinants of academic achievements in Botswana Junior Secondary Schools, Unpublished Ph.D Thesis, University of Chicago.

McNeal, R.B, (1999). Parental involvement as social capital: Differential Effectiveness on science achievement, truancy and dropping out. Social Forces 78(1), 117-144.

Nord, C.W; Brimhall, D \& West, V (1997). Fathers' Involvement in their children's schools. Washington, DC: V.S. Department of Education. ED 409, 125.

Nord, C.W., Lennon, J., Liu, B \& Chandler, K (2000). Home literacy activities and signs of children's emergency literacy, 1993 and 1999/NCES Publication 2000-026. Washington DC: National Center For Education Statistics.

Ogunniyi, M.B. (1996). Science, technology and mathematics"the problem of developing critical human Capital in Africa. International Journal of Science Education, 18(3), 267 - 284.
Okunola, O. M. (2003). Home and School Factors as determinants of early school adjustment of pre-school children in Ibadan municipality. $P h D$ Thesis, University of Ibadan, Nigeria.

Prophet, R.B (1990). Rhetoric and reality in science curriculum development in Botswana. International Journal of Science Education, 2(1), 13-23,

Reaney, L.M. Denton, K.L., \& West., J (2002), Enriching environments: The relationship of home educational activities, extra-curricular activities and community resources to Kindergatners' cognitive performance. Paper presented at the annual conference of the American Educational Research Association, New Orleans, LA.

Science Teachers' Association of Nigeria(1992). Raising the standard of performance in Public Examinations in Science, Technology and Mathematics. A West African Examinations Councils Symposium, University of Ibadan, Nigeria.

Scribner, J.D., Young, M.P., \& Pedroza, A. (1999). Building Collaborative relationships with parents. In P. Reyes, J.D, Sribner, \& A. P. Scribner (Eds), Lessons from high performing Hispanic schools: Creating learning opportunities (pp 36-60). New York: Teachers College Press.

Snow, C.E., Burns, S; \& Griffin, P (Eds)(1998). Preventing Reading difficulties in young children. Washington, DC. National Academy Press. ED 416 465.

Trusty, J (1999). Family Influences on Educational expectation of late adolescents. The Journal of Educational Research, 91(5) 260-270. 
Wasik, B.A. \& Bond, M.A (2001). Beyond the pages of a book: Interactive book reading and language development in preschool classrooms. Journal of Educational Psychology, 93(2), 243-250, EJ 638739.

What do we know about how kids learn? http://www.tryscience.org/parents/ss3.html.

Whitehurst, G.J \& Lonigan, C. J. (1998). Child development and emergent Literacy. Child Development, 69(3), 848-872. EJ S69 165.

Why Science matters for you and your child.

http://www.tryscience.org/parents/wsw_ma in.html

Yan, W \& Lin, Q (2002). Parent Involvement and Children's Achievement: Race and income differences. Paper presented at the annual Conference of American Educational Research. Association New Orleans, LA.

Yip, D.Y (2001). Promoting the development of a conceptual change model of science instruction in prospective secondary Biology teachers. International Journal of Science Teaching. 23 (7), 756. 